\title{
Long-term ecological change in the northern Wadden Sea
}

\author{
Justus E. E. van Beusekom • Karsten Reise
}

Published online: 2 February 2008

(C) Springer-Verlag and AWI 2008

The year 2007 was unusual for climate-related research. The IPCC report (2007) aroused public and political awareness. The report documented the unprecedented rise in global temperatures and raised many questions concerning the effects of the rise in global temperature. Efforts to keep the global temperature rise at about $2^{\circ} \mathrm{C}$ during this century are now high on the political agenda. Public interest in the effects of climate change is expressed by the fact that "Klimakatastrophe" (climate catastrophe) was chosen as the word of the year 2007 by the Society for the German Language.

Low-lying sedimentary coasts will be under pressure because of the combined effects of higher temperatures and the concomitant rise in sea level. It is noteworthy that the model-based IPCC estimate of $18-59 \mathrm{~cm}$ during the next century is much more conservative than the semi-empirical estimates by Rahmstorf (2007) of 50-140 cm. The impact of temperature and sea-level rise on coastal ecosystems is uncertain. Human impacts on the coastal ecosystem like eutrophication, discharge of toxic substances or diking aggravate the uncertainty. The analysis of time series is one way to distil the effects of past changes on the ecology of the Wadden Sea. Projecting them into the future may provide a glimpse of future coastal change. This again may help coastal managers to initiate appropriate measures to protect the goods and services provided by the Wadden Sea.

\footnotetext{
J. E. E. van Beusekom $(\bowtie) \cdot$ K. Reise

Alfred-Wegener-Institute for Polar and Marine Research,

Wadden Sea Station Sylt Hafenstrasse 43,

25992 List/Sylt, Germany

e-mail: justus.van.beusekom@awi.de

K. Reise

e-mail: karsten.reise@awi.de
}

The Island of Sylt lies in the northern Wadden Sea, a shallow tidal coastal sea in the southeastern North Sea (Europe) protected by barrier islands. This coastal ecosystem has been under human pressure ever since it was formed after the last ice age, some 8,000 years ago (Lotze et al. 2005). Biological research has a long tradition on this island and many of the recent changes have been documented. Already during the nineteenth century, Möbius (1877) investigated the macrobenthic community of nowextinct oyster beds. In 1924, the Littoral Station was established in List on Sylt as a field station of the Biologische Anstalt Helgoland. Early descriptions of the Wadden Sea around Sylt for instance by Nienburg (1927) and Wohlenberg (1937) serve as a baseline for the assessment of recent ecological changes. Several time series were started during the 1970s and 1980s, some of them persisting into the present day. From the 21-23 February 2007, we organized a workshop to assemble and discuss recent ecological change in the northern Wadden Sea (southeastern North Sea). The workshop was hosted by the AlfredWegener-Institute for Polar and Marine Research at the Wadden Sea Station Sylt. A total of 25 scientists discussed a broad spectrum of themes from sediments to parasites presented during 13 oral presentations and on four posters. The present volume contains eight original papers based on these presentations. Dolch and Hass (2008) describe a gradual loss of mud in Königshafen (a small bay at the northern end of the island Sylt near the Wadden Sea Station Sylt). Eutrophication seems to be on its return with decreasing winter nitrate concentrations (van Beusekom et al. 2008) and increased nutrient limitation during summer (Loebl et al. 2008). A recent increase in seagrass coverage fits within this trend (Reise and Kohlus 2008), but also hydrodynamics changes due to decreased storminess may be involved. Martens and van Beusekom (2008) observed that 
long-term zooplankton dynamics are strongly related to mean temperatures during the first 5 months of the year. Reise et al. (2008) describe irreversible changes of mud flat biota that occurred during the last seven decades and Büttger et al. (2008) report on changes in mussel beds and observe a recent proliferation of species that invaded the area during the past decades. Thieltges et al. (2008) conclude that parasites are a conservative component of coastal ecosystems. We end the special volume by depicting possible interactive effects of species introduction, eutrophication decline, future temperature rise and sea level rise on the Wadden Sea ecosystem (Reise and van Beusekom 2008).

The year 2007 was also unusual in terms of local weather in Sylt. The workshop took place in the middle of a 12-month period (July 2006 to June 2007) with water temperatures on average $2.27^{\circ} \mathrm{C}$ above the long-term mean. In our 35 year records $\left(10.7^{\circ} \mathrm{C}\right.$ until mid-December), 2007 probably will be the warmest year. We thank all the participants for their constructive contributions, independent experts for reviewing the manuscripts and students and staff of the Wadden Sea Station Sylt for their help and support during the preparation of the workshop. We are grateful for the financial support by the Foundation Alfred-WegenerInstitute for Polar and Marine Research. We thank Martina Loebl for bringing the unusual 2007 temperatures to our attention.

\section{References}

Büttger H, Asmus H, Asmus RM, Buschbaum C, Dittmann D, Nehls G (2008) Community dynamics of intertidal soft-bottom mussel beds over two decades. Helgol Mar Res 62. doi:10.1007/s10152007-0099-y

Dolch T, Hass HC (2008) Long-term changes of intertidal and subtidal sediment compositions in a tidal basin in the northern Wadden
Sea (SE North Sea) Helgol Mar Res 62. doi:10.1007/s10152-0070090-7

IPCC (2007) climate change 2007: the physical science basis. Contribution of Working Group I to the Fourth Assessment Report of the Intergovernmental Panel on Climate Change. Solomon S, Qin D, Manning M, Chen Z, Marquis M, Averyt KB, Tignor M, Miller HL (eds) Cambridge University Press, Cambridge, p 996

Loebl M, Colijn F, van Beusekom JEE (2008) Increasing nitrogen limitation during summer in the List tidal basin (northern Wadden Sea). Helgol Mar Res 62. doi:10.1007/s10152-007-0089-0

Lotze HK, Reise K, Worm B, van Beusekom JEE, Busch M, Ehlers A, Heinrich D, Hoffmann RC, Holm P, Jensen C, Knottnerus OS, Langjanki N, Prummel W, Vollmer M, Wolff WJ (2005) Human transformation of the Wadden Sea ecosystem through time: a synthesis. Helgol Mar Res 59:84-95

Martens P, van Beusekom JEE (2008) Zooplankton response to a warmer northern Wadden Sea. Helgol Mar Res 62. doi:10.1007/ s10152-007-0097-0

Möbius K (1877) Die Auster und die Austernwirtschaft. Verlag von Wiegandt, Hempel \& Parey, Berlin

Nienburg W (1927) Zur Ökologie der Flora des Wattenmeeres. I. Der Königshafen bei List auf Sylt. Wiss Meeresunters (Abt. Kiel) 20:146-196

Rahmstorf S (2007) A semi-emperical approach to projecting future sea-level rise. Science 315:368-370

Reise K, Herre E, Sturm M (2008) Mudflat biota since the 1930s: change beyond return? Helgol Mar Res 62. doi:10.1007/s10152007-0087-2

Reise K, Kohlus J (2008) Seagrass recovery in the northern Wadden Sea? Helgol Mar Res 62. doi:10.1007/s10152-007-0088-1

Reise K, van Beusekom JEE (2008) Interactive effects of global and regional change on a coastal ecosystem. Helgol Mar Res 62 . doi:10.1007/s10152-007-0102-7

Thieltges DW, Hussel B, Hermann J, Jensen KT, Krakau M, Taraschewski H, Reise K (2008) Parasites in the northern Wadden Sea: a conservative ecosystem component over four decades. Helgol Mar Res 62. doi:10.1007/s10152-007-0091-6

Van Beusekom JEE, Weigelt-Krenz S, Martens P (2008) Long-term variability of winter nitrate concentrations in the northern Wadden Sea driven by freshwater discharge, decreasing riverine loads and denitrification. Helgol Mar Res 62. doi:10.1007/s10152-0070092-5

Wohlenberg E (1937) Die Wattenmeer-Lebensgemeinschaften im Königshafen von Sylt. Helgol wiss Meeresunters 1:1-92 